\title{
CORRESPONDENCE
}

\section{LUDLOVIAN STRATIGRAPHY}

SIR,-I should like to reply to some of the points made by Holland, Lawson, and Walmsley in their discussion of my paper on Ludlovian stratigraphy.

In my thesis I established that at least two lithological units are diachronous, and they most certainly cannot be correlated with any of the new " combined units " of Holland et al. As a member of the Ludlow Research Group at that time, prior to the remapping of the type area, I abided by the stratigraphic procedure adopted by the Group, although I made it quite clear that I viewed it with considerable misgiving.

Biostratigraphic and lithostratigraphic units do not everywhere coincide, and "combined units" are meaningful only for the area in which they are defined. This may have been adequate for nineteenth century stratigraphers whose need was essentially for a descriptive stratigraphy, but the growing understanding of sedimentary processes and appreciation of the importance of diachronism has made the adoption of a dual classification imperative. The " combined units" of Holland et al. do not exist (as " combined units") outside of the Ludlow district. This is illustrated by the Aymestry Limestone, which is known to be diachronous, e.g. at Wenlock Edge the Aymestry Limestone is apparently younger than at Ludlow: is it then to be named the Upper Bringewood Beds or the Lower Leintwardine Beds, or is it not to be recognized as a separate entity at all ?

Although the lack of precision inherent in "combined units" makes correlation between neighbouring areas extremely difficult, it also engenders misunderstanding of sedimentary history and paleogeography. Such misunderstanding can have very important economic implications, and it is significant that petroleum geologists were among the first to insist upon a dual classification.

I, together with my fellow geologists who make " the common error of assuming that biostratigraphical units are necessarily time-stratigraphical units", believe with Jeletsky (B.A.A.P.G., v. 40, 1956) that biostratigraphy is the only approach practically available to us in erecting a time-stratigraphy. In order that they be practically useful stages must be defined by biostratigraphic units, and if the "combined units" of Holland et al. cannot be used for this purpose, then they have no business erecting stages.

In proposing Aymestry and Mocktree as stage names I am partly reverting to the original proposal of the Ludlow Research Group (Lud. Res. Bull., No. 5); in naming them after lithostratigraphic units I am following time honoured practice, and also that adopted by Holland et al. in using Whitcliffe. The argument that the Aymestry Limestone occurring in the Mocktree Stage at Wenlock Edge would have to change its name is nowhere substantiated in the literature. However, because Holland et al. insist that their "combined units " are also formations, each of their new stages will presumably be named after a lithostratigraphic unit.

I made it clear in my paper that I was not proposing a formal classification, but that my stratigraphic table was intended as an example of the kind of classification needed. A new, definitive classification should only be erected by the revisers of the type area stratigraphy, and this, I maintain, they have not done.

\section{Cía. Shell de Venezuela, APARTADO 19, MARACAIBO,}

12th January, 1963.

Colin Phipps. 